\title{
Motivasi Australia Memberikan Bantuan Luar Negeri kepada Indonesia dalam Menangani Penyebaran COVID-19 Tahun 2020-2021
}

\author{
Ilham Agustian Candra ${ }^{1 *}$, Arie Kusuma Paksi ${ }^{2}$ \\ ${ }^{1}$ Hubungan Internasional, Fakultas Ilmu Sosial dan Ilmu Politik, Universitas \\ Muhammadiyah Yogyakarta \\ ${ }^{2}$ Hubungan Internasional, Fakultas Ilmu Sosial dan Ilmu Politik, Universitas \\ Muhammadiyah Yogyakarta \\ *Korespondensi: ilham.a.isip18@mail.umy.ac.id
}

\begin{abstract}
This research focused to discuss the motivation behind Australia's foreign aid to Indonesia in order to tackle the transmission of COVID-19 in 2020-2021. According to data, the case of COVID-19 spreading in Indonesia has escalated continuously. Hence, Australia is concerned about providing foreign aid to Indonesia. The conceptual framework that was used in this article is the concept of national interest. The qualitative methods and descriptive analysis approach were also used in this research. Through library resources with collecting the data sourced from books, documents, journals, and electronic sources that the validity can be accounted for, this article explained that Australia as a country providing aid to Indonesia places interest in the health sector and the private sector. Furthermore, the result of this research concludes that the aid provided by Australia to Indonesia is an intention to defend Australia's national interests related to health research while strengthening the economic sector obtained from the results of cooperation amid the COVID-19.
\end{abstract}

Keywords: COVID-19, Foreign Aid, National Interest, Australia, Indonesia

\begin{abstract}
ABSTRAK
Penelitian ini berfokus untuk mendiskusikan tentang motivasi dibalik bantuan luar negeri Australia kepada Indonesia dalam menangani penyebaran COVID-19 tahun 2020-2021. Berdasarkan data, kasus penyebaran COVID-19 di Indonesia terus mengalami eskalasi sehingga Australia menaruh kepedulian dengan memberikan bantuan luar negeri. Kerangka konseptual yang digunakan adalah konsep kepentingan nasional. Metode kualitatif dan pendekatan analisis deskriptif juga telah digunakan dalam penelitian ini. Melalui studi pustaka dengan mengumpulkan data-data yang bersumber dari buku, dokumen, jurnal, dan media elektronik yang dapat dipertanggung jawabkan validitasnya, artikel ini menjelaskan bahwa Australia sebagai negara pemberi bantuan bagi Indonesia menaruh kepentingan akan sektor kesehatan dan sektor swasta. Selanjutnya, hasil penelitian ini memberikan simpulan bahwa bantuan yang diberikan oleh Australia terhadap Indonesia adalah suatu upaya untuk mempertahankan kepentingan nasional Australia terkait riset kesehatan sekaligus menguatkan sektor ekonomi yang diperoleh dari hasil kerja sama dimasa COVID-19.
\end{abstract}

Kata kunci: COVID-19, Bantuan Luar Negeri, Kepentingan Nasional, Australia, Indonesia

PENDAHULUAN

Hubungan baik antara Australia dan Indonesia didukung oleh kerjasama dalam berbagai bidang, terlebih juga 
ISSN 2614-4336

VDL. 7 No.I HAL. $14-29$

dengan letak geografis kedua negara yang berdekatan. Hal tersebut membuat Australia menjadikan Indonesia sebagai mitra atau prioritas utama dalam setiap kebijakan luar negerinya. Hubungan kedua negara dapat saling menjanjikan berbagai peluang kerja sama yang menguntungkan. Hal ini juga berangkat dari hubungan antar masyarakat dan kelembagaan yang substansial. Data dari Australian Government (2020) menunjukkan bahwa 85,700 orang kelahiran Indonesia telah tinggal di Australia terhitung hingga tahun 2018. Lebih lanjut, Indonesia adalah mitra dagang terbesar ke-12 bagi Australia (Australian Embassy, 2021).

Komitmen Australia dalam mendukung Indonesia telah tercermin sejak lama melalui bantuan luar negeri bernama Colombo Plan yang didirikan bersama dengan negara-negara persemakmuran pada tahun 1950-an, hingga membentuk lembaga resmi bantuan luar negeri bernama Australian Aid (AusAID) pada tanggal 1 Desember 1973. Dalam praktiknya, lembaga ini bertanggung jawab secara langsung kepada Kementerian Luar Negeri dan Perdagangan (DFAT) Australia. Program bantuan ini ditujukan untuk mencapai kepentingan nasional Australia dalam meningkatkan ekonomi Indonesia baik secara kelembagaan dan infrastruktur, pembangunan sumber daya manusia untuk masyarakat yang produktif dan sehat, serta pemberdayaan ekonomi dan politik bagi perempuan, penyandang disabilitas, dan kaum marginal. Ini menggambarkan keseriusan Australia terkait program bantuan guna memperdalam keterlibatan dalam menciptakan kawasan yang makmur dan stabil.

Dewasa ini, stabilitas dunia internasional sedang dihadapkan dengan krisis pandemi COVID-19 yang juga berdampak pada kerja sama internasional. Dalam kasus Indonesia, penyebaran COVID-19 terus mengalami eskalasi hingga saat ini. Data dari John Hopkins University Medicine dalam (CNN Indonesia, 2021) mencatat bahwa kasus konfirmasi paparan COVID-19 di Indonesia menyumbang 1,36 persen angka kematian secara global serta menempatkan urutan ke-17 dengan kasus terbanyak di dunia. Oleh karena itu, kondisi krisis seperti ini justru membutuhkan penanganan kolektif antar negara. Menteri Luar Negeri Indonesia, Retno Marsudi dalam International Coordination Group (ICG) juga berpendapat bahwa membangun kemitraan dan sinergi akan memperkuat stabilitas negara ditengah COVID-19. 
Australia dan Indonesia memiliki sejarah panjang dan telah berkomitmen untuk saling membantu dalam segala situasi, termasuk dalam memerangi COVID-19. Menanggapi situasi tersebut, Australia kemudian merumuskan kembali bentuk kemitraan pembangunan dengan Indonesia yang berfokus pada penanganan COVID-19 dalam kerangka kerjasama Indonesia COVID-19 Development Response Plan (Australian Government Department of Foreign Affairs and Trade, 2020). Adapun tiga pilar utama yang dikerahkan oleh Australia dalam bantuan luar negerinya meliputi: (1) Keamanan Kesehatan; (2) Stabilitas Pemerintahan; dan (3) Pemulihan Ekonomi.

Sebagai mitra utama Indonesia, Australia berinisiatif untuk memberikan insentif terhadap bisnis lokal, menciptakan ekonomi inklusif, membangun infrastruktur yang mendukung pertumbuhan, pengembangan sumber daya manusia untuk meningkatkan produktivitas, serta pemberdayaan ekonomi yang secara khusus ditujukan untuk kaum perempuan, penyandang disabilitas, dan kelompok marginal (DFAT, 2020a). Bantuan ini adalah bentuk kepedulian Australia dalam rangka mempercepat penanganan penyakit akibat persebaran COVID-19 di Indonesia.
Dikutip dari laman (Australian Embassy Indonesia, 2021), Duta Besar Australia, Gary Quinlan menjelaskan sebagai berikut.

"Australia dan Indonesia merupakan mitra dan teman dekat, sama seperti Indonesia membantu kebakaran hutan tahun lalu, kami senang dapat mendukung Indonesia dan menghadapi tantangan COVID-19 bersama-sama".

Dalam artikel ini, penulis akan memfokuskan penelitian pada bantuan luar negeri Australia kepada Indonesia dalam menangani penyebaran COVID-19 tahun 2020-2021. Beberapa penelitian terdahulu yang dijadikan rujukan dalam tulisan ini adalah penelitian milik (Davis, 2006; Eldridge, 1971; Rifaldy, 2020) yang juga menjelaskan bantuan luar negeri Australia menggunakan pendekatan kepentingan nasional.

Tidak dapat dipungkiri bahwa bantuan luar negeri yang diberikan Australia merupakan aset untuk mendapatkan eksistensi di negara penerima bantuan dan tentunya berbagai kepentingan nasional yang dibawa. Selain diharapkan dapat memberikan pembaruan penelitian, artikel ini bertujuan untuk menganalisa dan membuktikan secara empiris motivasi 
Australia memberikan bantuan luar negeri kepada Indonesia dimasa krisis COVID-19 hingga manfaat dibalik pemberian bantuan tersebut.

\section{METODE}

Penulis dalam mencari dan menjelaskan data yang digunakan dalam tulisan ini menggunakan metode kualitatif dan pendekatan analisis deskriptif. Adapun metode kualitatif adalah metode penelitian yang dilaksanakan pada seting tertentu yang terjadi dalam kehidupan nyata dengan fokus untuk menyelidiki dan memahami sebuah fenomena, seperti apa yang terjadi, mengapa itu terjadi, dan bagaimana itu terjadi (Chariri, 2009).

Sedangkan pendekatan analisis deskriptif analisis dapat diartikan sebagai prosedur pemecahan masalah yang diinvestigasi dengan menampilkan gambar subjek atau objek penelitian seperti individu, lembaga, kelompok dan masyarakat pada saat ini berdasarkan fakta tertulis, gambaran, dan sebagainya (Nawawi, 2015). Dalam tulisan ini menekankan pada data yang didapatkan melalui penelitian kepustakaan atau data sekunder yang didapat dari data valid yang diperoleh melalui buku, dokumen, jurnal, dan media elektronik yang semuanya mendukung proses penelitian.

Dalam tulisan ini juga telah digunakan teknis analisa korelasionis, dikarenakan tingkat unit eksplanasi dan unit analisanya adalah sama yaitu negara. Selebihnya, data yang telah dikumpulkan akan dikelompokkan sehingga membentuk proses generalisasi sebagai hasil akhir.

\section{HASIL DAN PEMBAHASAN}

Kuatnya interdependensi berakibat pada hubungan ekonomi antar negara yang membutuhkan bantuan dari negara pendonor atau pemberi bantuan. Hal tersebut tertuang pada kerjasama dalam rangka pemberian bantuan luar negeri yang kemudian menjadi instrumen utama negara-negara maju untuk menyertakan kepentingan nasionalnya. Hal ini selaras dengan yang dilakukan oleh Australia kepada Indonesia. Kondisi Indonesia yang masih menjadi negara berkembang juga menguatkan latar belakang Australia untuk berpartisipasi membantu pembangunan dan perekonomian. Tulisan ini akan menyajikan pembahasan tentang bantuan luar negeri Australia kepada Indonesia untuk menghadapi COVID-19 dan motivasi Australia dibalik pemberian bantuan luar negeri tersebut. 
Adapun untuk menjelaskan motivasi Australia tersebut, digunakanlah konsep kepentingan nasional menurut Thomas W. Robinson (1967) yang secara umum mengklasifikasikan kepentingan nasional kedalam enam variabel yaitu, (1) Primary Interest, yakni kepentingan nasional bertujuan untuk memberikan perlindungan atas wilayah dan pertahanan negara, kebudayaan, identitas politik serta keberlangsungan hidup terhadap gangguan luar. (2) Secondary Interest, merupakan kepentingan primer seperti melindungi warga negara yang berada diluar negeri. (3) Permanent Interest, yaitu kepentingan yang memiliki keterkaitan dengan periode atau jangka waktu tertentu. (4) Variable Interest, adalah kepentingan nasional yang berubah-ubah sesuai dengan opini publik dan situasi politik dalam negeri. (5) General Interest, yakni kepentingan nasional yang bersifat umum dan dapat berdasar pada letak geografis, jumlah populasi, aspek ekonomi, perdagangan, investasi, dan sebagainya. (6) Specific Interest, berarti kepentingan nasional berdasar pada fokus daerah, isu atau saat tertentu.

\section{Berdasarkan keenam variabel} kepentingan nasional diatas, maka konsistensi Australia dalam memberikan bantuan luar negeri ke Indonesia di masa
COVID-19 mengacu pada variabel Primary Interest dan General Interest. Dalam hal ini, Primary Interest dimaksudkan bahwa ancaman atau permasalahan yang ditimbulkan akibat penyebaran COVID-19 merupakan salah satu masalah yang dihadapi oleh Australia dalam rangka melindungi warga negaranya. Sementara, General Interest dipahami sebagai kepentingan aspek ekonomi yang didukung dengan letak dan posisi geografis Indonesia yang strategis bagi Australia.

\section{Hubungan Australia dan Indonesia di masa COVID-19}

Pandemi menjadi perdebatan dalam lingkup hubungan internasional melalui indikasi permasalahan lintas batas yang berimplikasi pada kerjasama. Namun, Joseph S. Nye Jr dalam (Syawfi, 2020), menggambarkan bahwa COVID-19 tidak akan berpengaruh besar akan hal-hal fundamental dalam globalisasi yang berlandaskan pada interndependensi. Pernyataan tersebut kemudian diperkuat oleh Laurent (2020) bahwa kerja sama atau aksi kolektif akan menjadi hal yang lebih relevan untuk diterapkan. Hal ini juga selaras dengan penyataan Menteri Luar Negeri Indonesia, Retno Marsudi dalam beberapa kesempatannya mengikuti forum 
Internasional. COVID-19 ini merupakan sebuah tantangan yang belum pernah dialami sebelumnya oleh dunia dan wilayah Indo-Pasifik. Australia yang melihat Indonesia sedang mengalami keterpurukan akibat penyebaran COVID19, dengan sigap memberikan bantuan luar negeri sebesar $\$ 255,7$ juta untuk tahun 2020-2021 (DFAT, 2020b).

Pertumbuhan Produk Domestik Bruto (PDB) Indonesia sendiri tercatat stabil dalam kurun waktu sepuluh tahun kebelakang, namun akibat dari penyebaran COVID-19 menyebabkan kontraksi terhadap perekonomian. Pada tahun 2020, pemerintah Indonesia sendiri telah memperkirakan sedikitnya 5,2 juta orang mengalami kehilangan pekerjaan akibat COVID-19. Meskipun ekonomi dan ketenagakerjaan menjadi sektor yang paling banyak disorot, namun dampak penyebaran COVID-19 ini juga telah melemahkan sektor penting lainnya seperti, wisata, manufaktur, transportasi, sosial, hingga sektor pangan. Dalam hal ini, Australia telah menaruh Indonesia sebagai negara prioritas untuk mendapatkan bantuan luar negeri dalam rangka menangani penyebaran COVID-19 sekaligus membantu kebutuhan utama Indonesia seperti yang telah ditetapkan oleh Komite Penanganan COVID-19 dan
Pemulihan Ekonomi Nasional. Australia kemudian memberikan bantuan kepada Indonesia untuk menangani COVID-19 melalui tiga pilar utama yaitu, (1) Keamanan Kesehatan; (2) Stabilitas pemerintahan; dan (3) Pemulihan Ekonomi. Adapun penjelasan mengenai ketiga pilar tersebut akan menjadi fokus lebih lanjut dalam pembahasan kali ini.

Keamanan Kesehatan: Data dari Centre for Strategic and International Studies dalam (Mantong, 2020) menunjukkan bahwa bantuan kesehatan merupakan hal yang fundamental dalam membangun rasa kepercayaan dan perdamaian, meskipun sering kali bantuan ini juga dapat memunculkan konflik. Australia sendiri telah membantu untuk negara-negara lain untuk menahan laju penyebaran COVID-19 dengan melakukan kampanye kesehatan, mendukung sektor kesehatan dengan memberikan peralatan dan pelatihan, hingga memfasilitasi layanan sanitasi. Dalam konteks Indonesia, tingginya kasus COVID-19 akan berdampak pada kesehatan regional yang tentunya menghambat berbagai kepentingan Australia.

Australia kemudian merespon tingginya kenaikan COVID-19 di Indonesia dengan memberikan bantuan 
luar negeri berupa alat-alat kesehatan hingga menyediakan penasihat ahli untuk Komite COVID-19 Indonesia. Keseriusan Australia dalam pilar keamanan kesehatan ini juga dibuktikan dengan kerangka kerjasama Indo-Pacific Centre for Health Security yang saat ini berkontribusi aktif dalam mendukung pemerintahan Presiden Joko Widodo untuk membangun sistem yang kuat untuk mencegah, mendeteksi, dan merespon COVID-19 serta ancaman kesehatan lainnya. Selanjutnya, pilar ini memberikan hasil yang signifikan dalam rangka memajukan kesehatan di Indonesia dimasa COVID-19. Hal ini dibuktikan dengan terdapat 693.000 wanita, pria, dan anak-anak telah mendapatkan bantuan darurat, 1.970.000 wanita dan pria mempunyai akses tambahan air dan 198.000 layanan sanitasi, serta penyediaan 100 ventilator dan perlengkapan medis untuk mendukung pengobatan COVID-19. Pemerintah Australia juga mengklaim bahwa mitra kesehatan internasionalnya akan turut berkontribusi dalam memberikan dukungan kepada Indonesia melalui pemberian layanan kesehatan yang berkualitas untuk menguatkan sistem keamanan kesehatan di Indonesia.

Stabilitas Pemerintahan: Regulasi yang efektif sangatlah dibutuhkan, mengingat jumlah populasi Indonesia yang lebih dari dua ratus tujuh puluh juta jiwa. Ini berdasar bahwa COVID-19 akan berpotensi untuk membunuh populasi dan lebih lanjutnya akan mengancam kesehatan negara tetangga (Hodge, 2020). Ketidakstabilan tersebut tentunya dapat memberikan ancaman serius bagi Australia, maka bantuan luar negeri dalam pilar ini fokusnya adalah membantu pemerintah Indonesia untuk secara berkala memberikan layanan dasar serta merancang dan menerapkan kebijakan ekonomi dan sosial yang efektif terhadap hadirnya COVID-19 (DFAT, 2020b). Australia juga mendukung Pemerintah Indonesia untuk merancang dan mengimplementasikan program yang berguna untuk mengatasi kesenjangan semua elemen masyarakat seperti penyandang disabilitas, lansia, dan pengangguran.

Sebagai mitra yang strategis, stabilitas pemerintahan Indonesia menjadi pertimbangan besar bagi Australia agar tetap dapat melancarkan kepentingan nasionalnya. Oleh karena itu, luaran bantuan luar negeri dalam pilar ini diharapkan dapat memperkuat perlindungan sosial, ketahanan pangan, pendidikan, hingga memastikan kebutuhan masyarakat Indonesia, khususnya masyarakat rentan telah terpenuhi. Hal ini 
dapat terlaksana melalui dorongan dari Australia yang mendukung masyarakat untuk melakukan tindak advokasi atas kebutuhan mereka serta mendukung pemerintah untuk meningkatkan aksesibilitas terhadap masyarakat rentan. Kemudian, kontribusi bantuan luar negeri Australia terhadap stabilitas pemerintah Indonesia dalam menghadapi COVID-19 meliputi: (1) Memperkuat sistem pemerintahan untuk memitigasi dampak COVID-19, termasuk bidang sosial, pendidikan dan hukum; (2) Mendorong keterlibatan masyarakat sipil dalam pembuatan kebijakan dan pelaksanaan program pemerintah; (3) Menjalin kerjasama antara lembaga sektor publik Indonesia dan Australia untuk bersama mengatasi permasalahan terkait keamanan dan stabilitas.

Pemulihan Ekonomi: Australia mendukung dan membantu memberikan saran kepada para pengambil kebijakan rangka memulihkan perekonomian di Indonesia. Spesifiknya, Australia sedang merumuskan opsi kebijakan untuk mendukung pemulihan bisnis dan Badan Usaha Milik Negara (BUMN). Disamping itu, Menteri Keuangan Republik Indonesia, Sri Mulyani, telah menerima dukungan finansial dari Australia berupa pinjaman uang sebesar \$1,5 miliar dolar Australia dan dapat dibayarkan kembali dalam kurun waktu 15 tahun. Program kerjasama IACEPA juga akan mendukung pemulihan ekonomi melalui peningkatan perdagangan dan investasi bilateral. Hal ini juga telah ditegaskan oleh Direktur Jenderal Perundingan Perdagangan Internasional, Iman Pambagyo, dalam suatu wawancara.

"Implementasi IA-CEPA tahun ini akan membantu kedua negara mendorong lebih cepat pemulihan hubungan perdagangan dan investasi IndonesiaAustralia saat pandemi COVID-19 ini berakhir.” (Mahadi, 2020)

Perdagangan dan investasi akan menjadi ruang kolaborasi untuk menanggapi dampak dari COVID-19 dan mengkoordinasikan berbagai tanggapan terhadap masalah ekonomi dalam tingkat regional maupun global. Bentuk bantuan luar negeri dalam pilar pemulihan ekonomi juga tidak hanya terbatas pada dorongan bisnis ataupun dorongan stabilitas keuangan di tingkat negara, namun juga terbukti telah membantu 200.000 perempuan dan kelompok rentan lainnya untuk mengakses peluang ekonomi serta mempromosikan penciptaan lapangan pekerjaan. 


\section{Motivasi Australia dibalik Pemberian}

\section{Bantuan Luar Negeri kepada Indonesia}

Dengan menggunakan pendekatan konsep kepentingan nasional, artikel ini membuktikan bahwa Australia sebagai negara donor atau pemberi bantuan telah menaruh kepentingan nasionalnya dalam sektor kesehatan dan sektor swasta. Ini berdasar pada mobilitas, jumlah penduduk Indonesia yang terpapar COVID-19 dan letak antara kedua negara yang saling berdekatan. Keterlibatan Australia pada sektor kesehatan didorong pada keinginan untuk melakukan perkembangan riset dan kepentingan lembaga kesehatan yang mana luarannya dapat dipergunakan untuk kolaborasi ilmiah serta memajukan identitas politik Australia di lingkup internasional. Pada sektor swasta, bantuan luar negeri kali ini adalah bentuk kepentingan untuk mengembangkan perekonomian melalui kerja sama antara sektor swasta milik Australia dengan negara penerima donor. Berikut merupakan pembahasan yang lebih mendalam tentang kepentingan nasional yang menjadi motivasi Australia dalam memberikan bantuan luar negeri untuk Indonesia dimasa COVID-19.

Sektor Kesehatan sebagai Katalisator Global Health Diplomacy oleh Australia: Keberlangsungan kerjasama antara Australia dan Indonesia pada bidang kesehatan telah menjadi daya tarik utama terlebih dalam masa COVID19, sebagaimana seperti yang disebutkan oleh Senator Hon Marise. Dalam hal ini, Australia kemudian berkontribusi untuk menurunkan penyebaran COVID-19 di Indonesia dengan memberikan bantuan kesehatan berupa: 1000 ventilator, 700 oksigen konsentrator, 170 silinder oksigen senilai 12 juta dolar, 40.000 alat tes swabantigen serta 2.5 juta dosis vaksin AstraZeneca. Australia sendiri telah mulai memberikan berbagai bantuan luar negeri kepada Indonesia sejak awal pandemi seperti pinjaman sebesar 1,5 miliar dolar yang didalamnya menyediakan 100 ventilator non-invasif beserta peralatan medis dan pengembangan laboratorium riset ditujukan untuk tercapainya tujuan dari percepatan G7 Summit tentang penyebaran vaksin pada wilayah indopasifik yang ditargetkan dapat terpenuhi pada tahun 2022 (Payne, 2021). Hal ini juga dapat berimplikasi pada pemulihan ekonomi pasca pandemi melalui pemberian dukungan finansial guna pemulihan ekonomi yang stabil dan berkelanjutan (DW.com, 2021).

Australia melalui Commonwealth Scientific and Industrial Research 
Organization (CSIRO) bekerja sama dengan Lembaga Biologi Molekuler Eijkman dan Bio Farma Indonesia telah menyatakan pengembangan riset vaksin merah putih yang kemudian ditargetkan dapat digunakan pada tahun 2022. Kolaborasi tersebut akan mengembangkan lebih banyak luaran ilmiah yang akan menerjemahkan hasil riset kesehatan menjadi produk komersial yang dapat diakses oleh khalayak luas (Suwanti, 2020). Kegiatan riset akan meliputi kerjasama tenaga ahli, penyediaan model pengujian vaksin, serta analisis data guna melakukan eksplorasi akan probabilitas kemunculan penyakit baru (Australian Embassy, 2020).

Terkait dengan kolaborasi tersebut, Professor Amin Soebandrio selaku Ketua Lembaga Biologi Molekuler menjelaskan bahwa tujuan riset kesehatan ini adalah pengembangan vaksin dan observasi penyakit menular varian baru. Bergabungnya Indonesia dalam kegiatan riset dengan CSIRO ini secara tidak langsung telah terintegrasi dengan data kesehatan global khususnya di wilayah indo-pasifik (Australian Embassy, 2020). Dalam dunia kesehatan, adanya kegiatan untuk melakukan riset dan pengembangan secara berkelanjutan sangat diperlukan guna analisis dan pembaharuan data untuk mendukung terwujudnya global health diplomacy. Riset yang dilakukan oleh Australia dengan Indonesia dalam bidang kesehatan turut menjelaskan integrasi bidang kesehatan serta pembaruan kebijakan luar negeri dan kebijakan publik (Gagnon \& Labonté, 2013).

Ekspansi farmasi dan penelitian biomedis memegang peranan penting dalam pemberantasan penyakit, terutama dalam pengembangan vaksin serta pengembangan varian obat baru yang resistan terhadap banyak penyakit. Investasi dalam pengembangan hubungan penelitian kolaboratif antara negara berkembang dan negara maju juga dapat menghasilkan peluang untuk pelatihan untuk berbagi sumber daya alam.

Upaya tersebut dapat dikatakan sebagai langkah perwujudan biosecurity yang membutuhkan pertimbangan penting seperti hubungan kritis antara sistem ekonomi, sistem transportasi, karantina, sistem kontrol, hingga mekanisme hubungan internasional yang juga memerankan peran saat menegosiasikan biosecurity lintas batas (Adams et al., 2008, pp. 319-321).

Dalam masa pandemi ini negaranegara asing melakukan intervensi kepada 
negara lainnnya didasarkan pada tiga rasionalisasi; (1) pandemi menghubungkan konflik nasional menjadi konflik regional, (2) Adanya kenaikan angka kemiskinan yang dapat merujuk pada kenaikan angka kriminalitas, (3) mengurangi aktivitas pasar potensial antar negara (Labonté \& Gagnon, 2010). Hal ini selaras dengan yang telah dijelaskan sebelumnya mengenai implikasi sektor kesehatan yang tidak stabil dapat mempengaruhi aktivitas ekonomi. Hal ini pula juga menunjukkan sektor kesehatan memiliki dependensi terhadap sektor ekonomi dalam pengadaan suplai kebutuhan medis dan riset kesehatan.

Bantuan luar negeri yang kemudian berujung pada kerjasama riset kesehatan dilakukan oleh negara-negara maju guna menunjukkan kapabilitasnya dalam membantu negara lain dalam kasus jangka panjang yang nantinya akan menguntungkan negara penerima atau negara pemberi bantuan. Kerjasama yang dilakukan dalam bidang kesehatan merupakan suatu upaya yang sering dilakukan oleh negara-negara maju, guna menunjukkan kapabilitas untuk melakukan 'intervensi' terhadap negara lain.

Dapat dilihat bahwa bantuan luar negeri ini kemudian melahirkan keuntungan bagi Indonesia sebagai negara penerima bantuan yang dapat terbantu dalam menangani percepatan pemulihan kasus COVID-19. Di samping itu Australia sebagai negara pemberi bantuan juga telah menuangkan keuntungannya kedalam variabel kepentingan nasional melalui peningkatan kolaborasi riset yang mana menguntungkan dalam hal perolehan dan perkembangan sampel baru sebagai perwujudan untuk melindungi warga negara Australia. Kondisi ini juga akan mendukung eksistensi dari global health diplomacy Australia terkait dengan realisasi pernyataan Perdana Menteri Scott Morison pada G7 Summit tentang penyediaan 20 juta vaksin bagi kawasan Indo-Pasifik pada tahun 2022 (The Indonesia Australia Business Council, 2021).

$\begin{array}{rcr}\text { Sektor } & \text { Swasta } & \text { sebagai } \\ \text { Pendongkrak } & \text { Bisnis } & \text { Domestik }\end{array}$

Australia: Telah termuat secara eksplisit dalam Australia Foreign Policy White Paper bahwa dengan berbagai aset, jaringan dan keahlian dengan bisnis akan meningkatkan dampak bantuan pembangunan dari Australia di berbagai negara berkembang di dunia, tidak terkecuali Indonesia. Selain itu, telah disebutkan juga bahwa diplomasi ekonomi dan komersial menjadi garis terdepan 
terkait keterlibatan Australia di lingkup internasional. Hal ini berdasar pada komitmen Australia untuk meningkatkan peluang global bagi perkembangan bisnis di negaranya. Adapun peluang tersebut diharapkan dapat menciptakan lebih banyak lapangan pekerjaan, pemanfaatan teknologi baru, hingga mendorong laju pertumbuhan ekonomi yang berkelanjutan (Department of Foreign Affairs, 2017).

Selaras dengan pembahasan diatas, Kementerian Luar Negeri dan Perdagangan Australia kemudian membentuk Operational Framework for Private Sector Engangement in Australia's Air Program sebagai suatu kerangka kerja sama yang ditujukan untuk mencapai kepentingan nasional Australia melalui keterlibatan perusahaan swasta milik Australia untuk menjalin kerja sama demi menyukseskan program pembangunan (Australian Government Department of Foreign Affairs and Trade, 2021). Kerangka kerja sama yang dibentuk pada tanggal 28 Maret 2019 ini melibatkan berbagai sektor perusahaan swasta baik dari sektor agraris, sektor pertambangan, sektor energi, sektor perbankan, sektor transportasi, sektor perdagangan, sektor teknologi, hingga sektor start-up. Pemerintah Australia melihat bahwa perusahan swasta ini merupakan salah satu sumber utama bagi pertumbuhan ekonomi, pendapatan nasional, dan lapangan pekerjaan di Australia.

\section{Pembentukan kerjasama antara} pemerintah dan sektor swasta pada masa pandemi ini sangat membantu untuk membangun dan mengembalikan stabilitas dan ketahanan baik dalam skala nasional maupun regional. Lebih lanjut, Australia kemudian meluaskan bentuk kerja sama antara pemerintah dan sektor swasta untuk membantu penanganan COVID-19 di Indonesia. Adapun sektor agrikultur menjadi prioritas utama dalam kerja sama kali ini. Mengacu pada laporan yang dipublikasikan oleh BAPPENAS dan Pemerintah Australia menunjukkan bahwa pada bulan Oktober 2020 terdapat 56\% petani Indonesia mengalami kesulitan akibat kenaikan harga pupuk yang disebabkan oleh keterbatasan persediaan di pasaran serta adanya pengurangan kuota pupuk bersubsidi oleh pemerintah Indonesia sebanyak 10\%. Kelangkaan dan kenaikan harga pada produk-produk pertanian ini dikhawatirkan dapat berkelanjutan sehingga menjadi ancaman terhadap ketahanan pangan hingga kenaikan tingkat kemiskinan masyarakat Indonesia yang bermata pencaharian pada sektor agrikultur (Anríquez \& Stamoulis, 2007). 
Bentuk kontribusi nyata dari Australia adalah kembali mengoptimalkan kerangka kerja sama Australia-Indonesia Partnership for Rural Economic Development (AIP Rural) dengan program khusus bernama Promoting Rural Income through Support for Markets in Agriculture (PRISMA) yang telah terlaksana sejak tahun 2013. Dengan mengimplementasikan skema kerja sama ini, pemerintah Australia yang bermitra dengan sektor swasta akan saling membantu dalam mengatasi dampak yang terjadi akibat dari persebaran COVID-19 terhadap sektor agrikultur di Indonesia. Kerja sama antara pemerintah Australia dengan sektor swasta ini bertujuan untuk mendorong pertumbuhan pertanian yang inklusif di Indonesia, mencegah terjadinya kelangkaan pangan yang diakibatkan oleh biaya produksi yang meningkat, megurangi kecenderungan kenaikan angka kemiskinan terutama di kalangan petani. Upaya dari kerja sama ini kemudian dapat berkontribusi dalam menciptakan hubungan pasar yang lebih baik bagi bisnis domestik di Australia.

Dapat terlihat bahwa hubungan interdependensi antara Australia dengan Indonesia masih terjalin dengan erat meskipun dimasa COVID-19. Kerja sama yang lahir dari sektor swasta ini selain memberikan dampak positif bagi Indonesia dimasa COVID-19, hal ini memang ditujukan untuk menyukseskan kepentingan nasional Australia. Bagi pemerintah Indonesia, program ini telah berkontribusi dalam menjaga ketahanan pangan serta mengurangi resiko peningkatan tingkat kemiskinan. Sedangkan, bagi pemerintah Australia, dengan kerangka kerja sama ini dapat membantu untuk mencapai pembangunan ekonomi berkelanjutan melalui kenaikan pendapatan nasional, pembukaan lapangan pekerjaan, dan menciptakan peluang bisnis domestik. Namun, skema kerja sama ini bersifat asymmetric interdependence atau tidak berdampak langsung terhadap pertumbuhan ekonomi Australia sebagai negara pendonor. Dengan terciptanya stabilitas pangan dan rendahnya tingkat kemiskinan Indonesia maka dapat membuka peluang kerja sama baru yang lebih luas dengan Australia di kemudian hari.

\section{SIMPULAN}

Kerja sama antar negara dalam bentuk bantuan luar negeri telah menjadi alternatif untuk mengatasi implikasi dari penyebaran kasus COVID-19. Melalui kerja sama yang sudah terjalin antara kedua negara, Australia kemudian menunjukkan komitmennya untuk 
membantu Indonesia dengan memberikan sejumlah bantuan luar negeri. Hal tersebut juga tentunya berangkat dari keprihatinan akan kondisi Indonesia yang terpuruk akibat lonjakan kasus COVID-19 sejak pertengahan tahun 2020. Bahkan, beberapa literatur telah menyajikan data bahwa persentase kasus COVID-19 di Indonesia turut serta menyumbang besaran persentase angka kematian secara global. Merespon hal tersebut, bantuan luar negeri Australia tersebut difokuskan kepada tiga pilar utama yaitu (1) Keamanan Kesehatan; (2) Stabilitas; dan (3) Pemulihan Ekonomi.

Kemitraan dimasa COVID-19 antara Australia dan Indonesia kemudian berkontribusi besar akan stabilitas dan pengelolaan kasus COVID-19 di Indonesia. Lebih lanjut, bentuk bantuan tersebut kemudian menghasilkan luaran positif bagi Indonesia. Selanjutnya, berbagai bentuk bantuan luar negeri yang diupayakan oleh Australia tentunya beririsan dengan kepentingan nasionalnya.

Dalam hal ini, motivasi Australia memberikan bantuan luar negeri kepada Indonesia dimasa COVID-19 ialah untuk menaruh kepentingan dalam sektor kesehatan dan sektor swasta. Terlepas dengan adanya berbagai kepentingan nasional, perlu diingat bahwa bantuan luar negeri merupakan suatu instrumen untuk mendorong sinergisitas antar negara kedalam hubungan yang lebih baik dalam menjaga stabilitas internasional dimasa COVID-19.

\section{DAFTAR PUSTAKA}

Adams, V., Novotny, T. E., \& Leslie, H. (2008). Global Health Diplomacy. Global Health Diplomacy, 27(4), 315-323. https://doi.org/10.1080/014597408 02427067

Anríquez, G., \& Stamoulis, K. (2007). Rural development and poverty reduction: is agriculture still the key? 4(1), 5-46.

Australian Embassy. (2020). Australia and Indonesia to Partner on COVID-19 Research.

Australian Embassy. (2021). Overview of Australia's aid program to Indonesia. https://indonesia.embassy.gov.au/ja $\mathrm{kt} /$ development-programs-inindonesia.html

Australian Embassy Indonesia. (2021). Australia Provides Additional Support to Indonesia's COVID-19 Response. https://indonesia.embassy.gov.au/ja kt/MR21_003.html

Australian Government. (2020). Permanent migration from Indonesia.

https://www.homeaffairs.gov.au/res earch-andstatistics/statistics/countryprofiles/profiles/indonesia 
Australian Government Department of Foreign Affairs and Trade. (2020). Partnerships for recovery: Australia's covid-19 development response.

Australian Government Department of Foreign Affairs and Trade. (2021). Private sector partnerships. https://www.dfat.gov.au/developme nt/who-we-work-with/privatesector-partnerships

Chariri, A. (2009). Landasan filsafat dan metode penelitian kualitatif. In Workshop Metodologi Penelitian Kuantitatif dan Kualitatif, Laboratorium Pengembangan Akuntansi (LPA), Fakultas Ekonomi Universitas Diponegoro Semarang, 31 Juli - 1 Agustus 2009.

CNN Indonesia. (2021). Indonesia Sumbang 1,09 Persen Kasus Corona Dunia. https://www.cnnindonesia.com/nasi onal/20210207032608-20603208/indonesia-sumbang-109persen-kasus-corona-dunia

Davis, T. (2006). Does Australia have an international development assistance policy?: National interest and foreign aid policy making.

Department of Foreign Affairs. (2017). 2017 Foreign Policy White Paper.

DFAT. (2020a). Indonesia-Australia Comprehensive Economic Partnership Agreement | Australian Government Department of Foreign Affairs and Trade.

DFAT. (2020b). PARTNERSHIPS FOR RECOVERY AUSTRALIAN OFFICIAL DEVELOPMENT
ASSISTANCE \$4 BILLION.

DW.com. (2021). KTT G7 Agendakan Vaksinasi dan Pemulihan Ekonomi

https://www.dw.com/id/ktt-g7agendakan-vaksinasi-danpemulihan-ekonomi/a-56570692

Eldridge, P. (1971). Australian aid to indonesia: Diplomacy or development? Australian Outlook, 25(2), 141-158. https://doi.org/10.1080/103577171 08444405

Gagnon, M. L., \& Labonté, R. (2013). Understanding how and why health is integrated into foreign policy - a case study of health is global, a UK Government Strategy 2008-2013. Globalization and Health, 9(1), 119. https://doi.org/10.1186/17448603-9-24

Hodge, A. (2020, April 11). Coronavirus: Indonesia in need is the region's nightmare. The Australian. https://www.theaustralian.com.au/i nquirer/coronavirus-indonesia-inneed-is-the-regionsnightmare/newsstory/1b2173a13357bccf22997fc6a eea $0 \mathrm{fb} 1$

Labonté, R., \& Gagnon, M. L. (2010). Framing health and foreign policy: lessons for global health diplomacy.

Laurent, L. (2020). Coronavirus Fight: Stop Shutting EU Borders And Work Together - Bloomberg. https://www.bloomberg.com/opinio n/articles/2020-03-20/corinavirusfight-stop-shutting-eu-borders-andwork-together

Mahadi, T. (2020, May 10). Bakal efektif 
di tahun ini, IA-CEPA bisa dorong ekonomi di tengah pandemi. Kontan.Co.Id.

https://nasional.kontan.co.id/news/b akal-efektif-di-tahun-ini-ia-cepabisa-dorong-ekonomi-di-tengahpandemi-1

Mantong, A. W. (2020). Keamanan Kesehatan dan Kebijakan Luar Negeri Indonesia pada Masa COVID-19: Rekomendasi Awal. CSIS Commentaries, April, 1-5.

Nawawi, H. (2015). Metode Penelitian Bidang Sosial. UGM Press.

Payne, H. M. (2021). Australia partners with Indonesia for COVID-19 response. Minister for Foreign Affairs.

Rifaldy, Y. (2020). Melihat Latar Belakang Australia Dalam Memberikan Bantuan Luar Negeri ke Kawasan Pasifik. Jurnal Hubungan Internasional, 13(2), 185. https://doi.org/10.20473/jhi.v13i2.1 8738

Robinson, T. W. (1967). A National Interest Analysis of Sino-Soviet Relations. International Studies Quarterly, 11(2), 135. https://doi.org/10.2307/3013925

Suwanti. (2020). Indonesia-Australia dorong kerja sama kesehatan via lembaga penelitian. Antara News.

Syawfi, I. (2020). Implikasi Pandemi Covid-19 Terhadap Hubungan Internasional: Menuju Dunia Paska-Liberal. Jurnal Ilmiah Hubungan Internasional, O(0), 2329.

https://doi.org/10.26593/jihi.v1i1.3 864.23-29
The Indonesia Australia Business Council (IABC). (2021, July 7). Australia partners with Indonesia for COVID-19 response. https://www.iabc.or.id/statementby-the-australian-minister-forforeign-affairs-senator-the-honmarise-payne-australia-partnerswith-indonesia-for-covid-19response

\section{PROFIL SINGKAT}

Penulis lahir di Yogyakarta, 24 Agustus 2000. Penulis terafiliasi dengan Departemen Hubungan Internasional, Fakultas Ilmu Sosial dan Ilmu Politik, Universitas Muhammadiyah Yogyakarta. Ketika memasuki ranah akademis, penulis aktif dalam LSM, organisasi maupun kegiatan kemahasiswaan. Saat ini, penulis memiliki ketertarikan dalam bidang riset. Hal ini Ia tuangkan melalui keikutsertaannya sebagai Ketua Riset dan Inovasi Laboratorium Hubungan Internasional (UMY), Tim Media dan Publikasi Center for Southeast Asian Social Studies (UGM), hingga mendirikan perusahaan rintisan bernama Bahas Apa Indonesia. 